

E-ISSN: 2706-9117 P-ISSN: 2706-9109 IJH 2020; 2(2): 78-80 Received: 20-06-2020 Accepted: 25-07-2020

Dr. Swati Kumari P.S.- L.N.M.U. Campus Dist- Darbhanga, Bihar, India

\section{Peasants response towards non- co-operation movement in Bihar}

\section{Dr. Swati Kumari}

DOI: $\underline{\text { https://doi.org/10.22271/27069109.2020.v2.i2b.47 }}$

\begin{abstract}
Bihar has contributed much to the origin and growth of religious and political ideas and institutions from the ancient time to the present Bihar has a great history of its own. The atmosphere created by Swami Vidhyanand and also contributed to the peasants political working and activities during the noncooperation days. Gandhi had to support the farmer with the hope they would, one days or the other, relalise the real concern of Gandhi service to the poor is service to the God.
\end{abstract}

Keywords: Peasants, Mahatma Gandhi, political, Darbhanga, movement, landlords

\section{Introduction}

The peasants of Bihar created a new chapter of history during non-co-operation movement. The programmes of the movement were urban in character, Bycott of the government services, offices, courts, Schools and other institutions was for the urban people, But Bihar the non- co-operation movement extended in rural areas on a large scale. Bihar witnessed anti liqour movement in rural areas which were not included in the programme of non-cooperation movement. As several places of peasants of Bihar became violent and looted the Hats and Bazars and confronted with the local police and administration. No doubt, the peasants of Bihar presumed and convinced that Mahatma Gandhi has come for their rescue from the oppressions of feudal and colonical elements and they went beyond the non- violent satyagraha not to disobey the Mahatma, but only to fulfil the will of the Mahatma to end injustice, oppression, poverty, indebtness and the other curses of the peasantry of Bihar. The present paper analysis the other side rural dimension of non- co-operation movement. Bihar has contributed much to the origin and growth of religious and political ideas and institutions from the ancient time to the present Bihar has a great history of its own ${ }^{[1]}$. Despite hostile conditions generated by the British Colonical imperialism parading in Bihar during the first half of 19th century and later in the $19^{\text {th }}$ and $20^{\text {th }}$ century agriculture did shaw some progress and the peasantry in Bihar began to conceive the seeds of discontent against the Raj's inimical trends and behaviours towards them ${ }^{[2]}$.

In September 1920 the Indian National Congress launched the non-co-operation movement against the British administration of India under the direction of Mahatma Gandhi. The Champaran experiment of Gandhi worked to being the common peasantry towards the nationalism courses. The congress in Bihar for the cause of Gandhi and accepted his programme of the non-cooperation as its offical policy in September $1920^{[3]}$.

The non-cooperation of Gandhi with the council vote being strongly supported by the Bihar peasantry delegates. Already, in August the Bihar congress at her Bhagalpur meet has supported in for own Gandhi's non-cooperation programme peasants participation during the non-cooperation movement also strength from the social tension and social feeling which had got crystalized during the anti-Indigo protests in north Bihar Because of ethnic identity between European planters and British officer they supported each other politically ${ }^{[4]}$. The atmosphere created by Swami Vidhyanand and also contributed to the peasants political working and activities during the non- cooperation days. We saw that in Bihar in 1920-22 non-cooperation received considerable support. Small landlords and rich peasants took the lead in protests ${ }^{[5]}$.

In India the Non-cooperation of 1920-23 acquired the character of a 'Chameleon' Compaignt ${ }^{6}$ taking colour from its surrounding.
Dr. Swati Kumari

P.S.- L.N.M.U. Campus

Dist- Darbhanga, Bihar, India 
In Bihar The movement received impetus from the Khilafat movement, interacted with anti-indigo protest, and in addition provided a channel for the expression of a variety of peasant discontents. Though members of town and village elites took the leading part in the movement middle and poor peasants and towns folk also participatiot. in the movement actively as well as passively. The movement gave the apparatus of British rule in province a Severetck In addition; the movement raised the level of political consciousness of the peasantry ${ }^{[7]}$. It also made them conscious of their sad economic plight engineered by the landlords.

The constitutional concessions were less rapid and less substantial than many had hoped, and thus their implementation created as much animosity as it won support. And owing to build up of the Raj control in Bihar, and particularly because of the Zamindari System. Government had few resources art its disposal after it had covered the cost of revenue collection and of seeing 'that the districts remained quiet ${ }^{[8]}$ Hence it could spend little on social and administrative services which might have reaped a valuable harvest of support. Through intervention in local political areas pattern of rule. It did not have the tendency or the capacity to meet. A sense of disappointment eneloped the peasantry. Men of national bent amongst the rising middle class had supported the Indian Home Rule Movement between 1915 and 1918 and had participated in

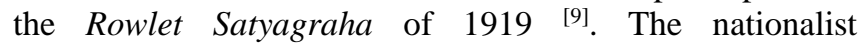
movement in Bihar had by the year 1920, taken in its fold only a limited section of the whole society, the middle class. But the champaran experiment of Gandhi worked to being the common peasantry towards the natinoalist causes. The congress in Bihar took the cause of Gandhi and accepted his programme of the Non-cooperation as its official policy in September 1920. The Non- cooperation of Gandhi with the Crucial vote being strongly supported by the Bihar peasantry delegated, In August. The Bihar Congress at her Bhagalpur meet has supported in favour, of Gandhi's NonCooperation programme ${ }^{[10]}$

It had been argued that as the Bihar congress, being chiefly dominated by small landlords and rich peasants as well as growing middle class intelligenesia, had feeble chances of coming successful against the large landlords. It opted to adopt the boycott of the election ${ }^{[11]}$. But side by side the fact of growing militancy of peasants against the landlords and the Raj modelled on the Gandhian awareness of the situation had their effects on the decision. Gandhi had indeed influenced a large number of rich peasants to come to the national front, i.e. the congress. Rajendra Prasad Comments that the congress meeting in Bhagalpur town in August 1920 was the first Bihar congress conference 'Where delegates.... were drawn largely from outside the professional classes' ${ }^{[12]}$. It were the peasant delegate, at the Bhagalpur congress who secured the passing of the Noncooperation resolution by voting as a block in its favour. ${ }^{13}$ An another fact needs to be clarification, mainly from the stand point of strategy. It is to be recalled that one Swami Vidyanand had started a movement in support of the peasantry against the oppression of Darbhanga Raj in 1920. The movement was being organised and fought almost on the basis of class struggle, particularly hostile to the Gandhian way of the class harmony. Therefore it conflicted with the efforts of the Bihar Congress, which stood behind the way of Gandhi, to promote social harmony and a united landlord-peasant front against British rule. As the way of the Swami, in the eyes of Gandhi and his congress co-workers. Both Gandhi and Bihar congress tried to enlist the support of the peasantry to the Non-cooperation cause as the most suitable means of attaining Swaraj. This consideration became important when the Swami, after at first supporting Non-cooperation, charged his mind and ran in the November 1920 elections. By calling for an electoral boycott in the name of the wider social and national interest the Bihar congress could attempt to represent the Swami as an adventurer out of his own ends ${ }^{[14]}$. It has been so said that in mid December the provincial government told the Government of India that the main impact of the movement had been in urban areas and particularly among students, and the peasantry of the countryside had remained quiet. But during December the movement received fresh impetus from the peasantry and the volume of political consciousness and activities was quite raised due to Gandhi's visit ${ }^{[15]}$.

As a result of Gandhi's visit and also by the Nagpur congress reaffirmation of the Non-cooperation programme considerable political activity and political consciousness among peasantry developed in Bihar during 1923. In addition to the large volume of support coming from the urban centers the movement attracted support from a broad spectrum of the peasantry in many parts of the countryside. The boycott of foreign cloth received good response. Volunteers would go from house to house collecting clothes made of foreign cloth, and the peasantry would support to light a bonenefire of the same ${ }^{[16]}$.

Such a response was also received on the question of withdrawing from government schools by parents in villages. The alternative national institutions of education were established. Government law courts were bycotted peasantry accepted the jurisdiction of congress organised 'National panchayats' [17] Peasants were also drawn around the issue of temperance movement. The movement, as its natural corollary, also gave occasions for the poor to protest against the Raj, particularly to express their discontent with the rising price of food commodity. In January and February of 1921 food grains prices had reached high levels and they were in short supply too. In such a situation many incidents of Hat looting occurred. Four such incidents in Purnea and Bhgalpur each, two in north Monghyr, Six in Darbhanga and nineteen in Muzaffapur are recorded. The indicants usually started when some one, in the name of Gandhi or Swaraj demanded lowering of price and there upon when dealers objected ${ }^{[18]}$

A characteristic feature of the peasant politics reflected in Saran. There the story got spread that the God Jagganath had began working with Gandhi and that anyone worshipping Gandhi would be thus worshipping the God Jagganath himself ${ }^{[19]}$. Similar indicents and rumours spread elsewhere too ${ }^{[20]}$ 'Peasants' attacks on police ${ }^{[21]}$ during the movement may be explained along the line. The arousal of messianic expectations among the peasantry and the trend towards violence during the movement, caused worry for the leader and in congress 'inconsistency' involved in peasant politices ${ }^{[22]}$ The movement being not sufficiently disciplined and organised ${ }^{[23]}$. But it needs to be noted that a popular peasant movement like that of Non-cooperation has naturally a tendency to drift away from the main plank and it is never possible to keep it within the desired dicipline of the highest command. And Gandhi was perfectly aware of 
it. Hence he did not withdraw the movement until ChauriChaura.

The congress at Nagpur had also decided that the production and use of Swadesi cloth would be an emphatic item of the Non-cooperation movement ${ }^{[24]}$. The most spectacular political outrage of the peasantry occured in late December 1921 when 200 men innaded the Sonbarsa thana on the northern frontier of Muzaffarpur ${ }^{[25]}$. Following the Nagpur resolutions South Bihar also witnessed political consciousness. Student, teachers and peasants in villages rose ${ }^{\mathbf{2 6}}$ Panchayats were established and Swaraj thanas were formed meetings were organised and speeches delivered. Peasant leaders of the movement ran with Gandhi.

Even the champaran movement was the point of departure congress in Bihar. The congress had then on no hesitation supporting any peasant movement which was directed against. British Government or European planters. Although even here was support was limited and it sow to it that the movement did not go out of its hands. It was concerned about the fact that any peasant movement must not threaten the rural power structure. Any threat to the established social structure would threaten their class interests and hence their reluctance to lend support to the peasant movement ${ }^{[27]}$. The spirit of Non-cooperation, it must be acknowledged had removed the fear of authority from the hearts of the peasantry and the call to stop the payment of taxes to the government certainly emboldened them to withhold payment to their landlords. This the congress, especially in Bihar, never wanted. So it hardly supported the cause of peasants against their landlords.

In this perspective I want to conclude this topic with his view of previous time our population mainly depends upon agriculture and only few changing this time but peasants problem were not solve. And, unfortunately, they were not bold enough to advance through the way of Gandhi nonviolent war against self-interests of the old orthodox congressmen. Hence Gandhi had to support the farmer with the hope they would, one days or the other, relalise the real concern of Gandhi service to the poor is service to the God.

\section{Reference}

1. Datta KK.Op. Cit. 2.

2. Brown, Gandhi's Rise to power, 315-16.

3. Henningham. op. cit. P. 90, Brown Gandhi's Rise to power, Op. Cit, 307-08.

4. Forrest to GBO Chief Secretary, 2nd July 1921, PSF 37, BSA, Patna, 1921.

5. Lakshmi, Mishra, 'An account of Non- cooperation on movement'. PSF No. 434, BSA, Patna, 1923.

6. Brown JM. Gandhi's Rise to power, Op. Cit, p. 322; Shahid Amin, Gandhi as Mahatma in Guha, Subaltern Studies 111. Delhi, 1-62.

7. Henningham, Op. Cit, 91.

8. Anil Seal. 'Imperialism and Natinalisam in India' in Gallaghar Johuson and seal. (eds) Locality, Province and Nation essays on Indian polities. 1870-1940 London, 1973, 8.

9. Henningham, Op. Cit, 94.

10. Brown, Gandhi's Rise to power, Op. Cit, 269-70.

11. 'bid, 253, 260, 261.

12. Prasad, Mahatma Gandhi, 40.

13. Henningham, Op. Cit, 95.

14. Government of Bihar and orissa, Fortnighly Report I (GBOKRI) 1920. Political special file (PSF) S, 1920
Bihar state Archives (BSA) Brown, Gandhi's Rise, Op. Cit., 288.

15. Badrinath Upadhya, Reply to 'Open letter' printed in the Searchlight steam press with a forward from an alleged Sanyasi calling himself Swami vidyanand, Bankipore.

16. Brown, Gandhis Rise to power pp. 309-12. W. Swain, Confidential Report, 25 April, 1921, G.B.O. P.S.F., 37, 1921 BSA.

17. Ibid.

18. Reports of Hat looting PS. of No. 21, 1921; Forrest. Tirhut commissioner to rainey CoBo Chief Secretary, 20. January 1921, P.S.K.N. 12, 1921; R.S.F. Macrae, Deputy Inspector General Police to GBO Chief Secretary, 20 Jan 1921, PSF W. 21, 1921, Purnea Special Report case 11. Report 11, 19 Feb. 1921. BSA Patna.

19. Extract from the diary of Gopalganj police inspector quoted in Henningham, Op. Cit., 99.

20. Ibid, for detail also sec. SIA min, Gandhi as Mahatma in Ranjit Guha (ed.) Subal tern studies III. Henningham, Op. Cit., 99-100.

21. Hemingham, op.cit.; cit, 99-100

22. Ibid.

23. Ibid.

24. Blow, Gandhi's Rise to power, 313.

25. Synopsis of History of NCO movement, PSF 286, 1924, BSA, Patna.

26. For detail sec, K.K. Datta, Op. Cit, I, 322-324, The Searchlight, 16th March, 1921; Prasad, Atmakatha, p. 136.

27. Dutta KK, Op. Cit, 329-30. 